\title{
American Tegumentary Leishmaniasis and Flow Cytometry: A Review
}

Oliveira $\mathrm{BC}^{1,2^{*}}$, Mendes $\mathrm{APO}^{2}$, Castro MCAB $^{2,3}$ and Hernandes VP2

${ }^{1}$ Universidade Federal de Pernambuco, Inovação Terapêutica, Recife, Pernambuco, Brazil

${ }^{2}$ Centro de Pesquisas Aggeu Magalhães, FIOCRUZ, Recife, Pernambuco, Brazil

${ }^{3}$ Centro Acadêmico de Vitória, Núcleo de Enfermagem, Universidade Federal de Pernambuco, Vitória, Pernambuco, Brazil

${ }^{*}$ Corresponding author: Oliveira BC, Departamento de Imunologia, Centro de Pesquisas Aggeu Magalhães/Fiocruz, Av. Moraes Rego s/n, Cidade Universitária, 50670-420, Recife, Pernambuco, Brazil, Tel: 55-81-21012631; Fax: 55-81-21012640; E-mail: oliveira.cbeatriz@gmail.com

Rec date: Dec 24, 2015; Acc date: Mar 14, 2016; Pub date: Mar 21, 2016

Copyright: (C) 2016 Oliveira BC, et al. This is an open-access article distributed under the terms of the Creative Commons Attribution License, which permits unrestricted use, distribution, and reproduction in any medium, provided the original author and source are credited.

\begin{abstract}
American Tegumentary Leishmaniasis (ATL) is a parasitic disease caused by protozoans of the genus Leishmania and transmitted by the bite of sandflies. It is considered neglected due to its high incidence and morbidity, mainly in developing countries. The treatment for this disease besides expensive, is toxic and has limitations such as resistance, both from the parasite and the host; and invasiveness, making it not quite acceptable for some patients. There is still no available vaccine for the disease, what makes the correct diagnosis the better alternative to guide the treatment and therefore manage it. The diagnosis of suspected cases has to gather epidemiological, clinical and laboratorial data, since the disease can be misdiagnosed with other dermatological conditions. Immunological methods are commonly used for detecting and monitoring diseases, and the main techniques used in the routine for ATL are the Montenegro Skin Test, Enzyme-linked Immunosorbent Assay, Immunofluorescence Assay and Western Blot. Although these approaches have good sensitivity levels, they lack on specificity and have some limitations like crossed-reactions with other diseases caused by trypanosomatid parasites. One different serological approach, which is becoming an alternative method for the diagnosis of this disease, is Flow Cytometry; it has shown balanced levels of specificity and sensitivity and also a better accuracy when compared to other methods used in routine. Therefore, this article shows the recent advances on the diagnosis of ATL by flow cytometry and by using the findings on the literature, aims to guide researchers on what should be the focus to have a better diagnostic method for this disease.
\end{abstract}

Keywords: American tegumentary leishmaniasis; Flow cytometry; Diagnosis

\section{Introduction}

American tegumentary leishmaniasis (ATL) is a neglected vectorborne disease, transmitted by sand flies of the genus Lutzomyia. Currently, there have been reported approximately 1.5 million cases per year, comprising the two main clinical forms of the disease: cutaneous leishmaniasis (CL) and mucocutaneous leishmaniasis (ML). $\mathrm{CL}$ is primarily found in regions of South America and Middle-East, and almost $90 \%$ of ML cases occur in Brazil, Peru and Bolivia [1,2].

Currently, according to the World Health Organization, more than 20 species of Leishmania capable of causing the disease have been reported [3]. CL is the most prevalent form of ATL, and it can be caused by the species: Leishmania aethiopica (L. aethiopica), L. major and $L$. tropica in the old world; and $L$. amazonensis, $L$. braziliensis, $L$. mexicana, $L$. venezuelensis, $L$. guyanensis, $L$. panamensis, and $L$. peruvianain the new world; and for ML, the causative species are: $L$. panamensis, L. peruviana, L. braziliensis and L. guyanensis (Figure 1).

The clinical forms of ATL will depend on the vector, the parasite and also on the immunological and genetic features of the host $[4,5]$. The infection might be asymptomatic or cause serious skin damages on the patient, ranging from localized cutaneous lesions to a destructive involvement of the nasal and oral mucosa [6], (Figure 2).

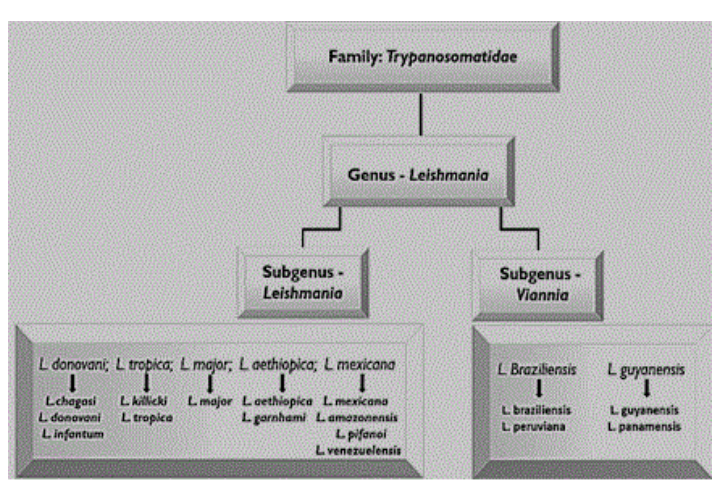

Figure 1: Etiological agents of American Tegumentary Leishmaniasis.

To all clinical forms of ATL, the treatment is based on the parenteral administration of pentavalent antimonies, or when not effective, antibiotics and antifungal agents $[7,8]$. This treatment presents certain level of toxicity, which can cause several side effects; also, the success index on the first cycle of treatment is only $16 \%$. The disease does not have an efficient cure criterion, this being based solely on the complete healing of the lesion [9]. Furthermore, there are no available vaccines for the disease, in spite of the great effort being put on over the decades. There is still a lack of knowledge about Leishmania spp. pathogenesis as well as the complexity of the immune response which 
is required to eliminate the parasite. That is why an adequate treatment and the development of an efficient vaccine are not a reality yet $[10,11]$.
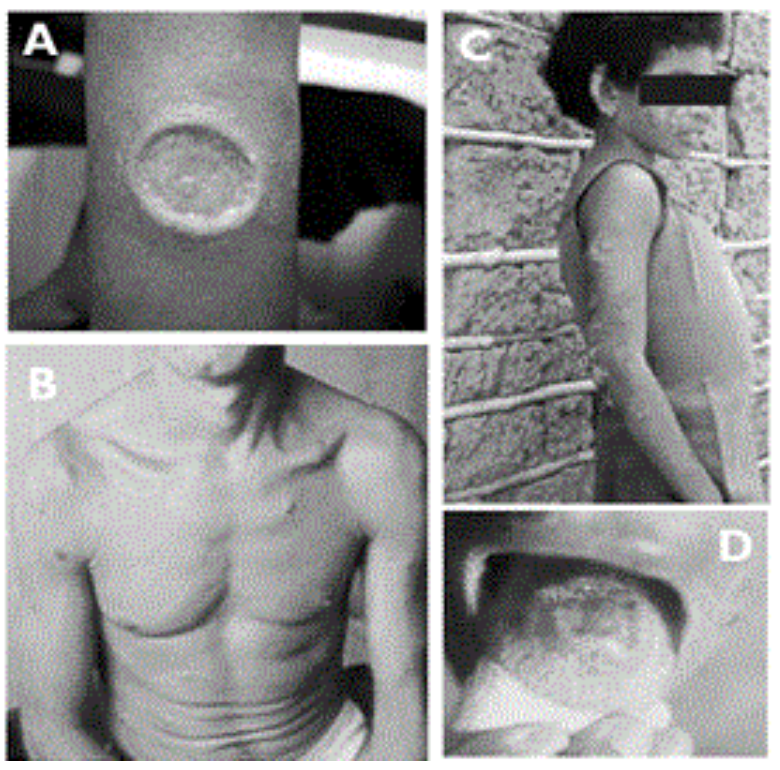

Figure 2: Clinical forms of American Tegumentary Leishmaniasis. A) Localized form; B) Disseminated form; C) Diffuse form; D) Mucocutaneous form - Rare case of involvement of the tongue. BRASIL (2007) [7].

\section{Diagnosis}

Due to the absence of a gold-standard method to diagnose the disease, there is a need to associate epidemiological, clinical and laboratorial aspects. In addition, the resemblance of the ATL lesions with other skin diseases makes differential diagnosis a useful tool to avoid an incorrect conclusion. Herein we discuss general features of the commonly used methods for the diagnosis of ATL focusing on those using flow cytometry.

\section{Epidemiological and clinical diagnosis}

For the epidemiological and clinical diagnosis it is important to have information about the habitat, leisure and work activities of the patients [12]. Also, it is useful to know if the individuals have travelled to endemic regions due to the expansion of transmission in urban areas [13]. Since ATL can be misdiagnosed with other dermatological diseases, to know where the patient comes from and where he went over the last weeks is important to know if it is a vector-borne disease, infectious disease or fungal disease.

As mentioned before, ATL presents difficulties on its clinical diagnosis due to the similarity of the lesions with different illnesses such as cutaneous tuberculosis, leprosy, tropical ulcer, syphilis, neoplasm and even some kinds of carcinomas and lymphomas $[8,14]$. On ML lesions, one might observe infiltrating or vegetative ulcers [15].

The clinical diagnosis can be performed based on the characteristics of the patient's lesion associating it with the anamnesis and the epidemiological data. This diagnosis can also be complemented by the Montenegro skin test (MST) and by the therapeutic response. However, laboratorial methods are essential for the differential diagnosis with other diseases $[7,14]$.

\section{Laboratorial diagnosis}

Since there is no gold-standard method to diagnose ATL, it is based on the association between immunological, molecular and parasitological assays. Figure 3 summarizes the methods for each approach.

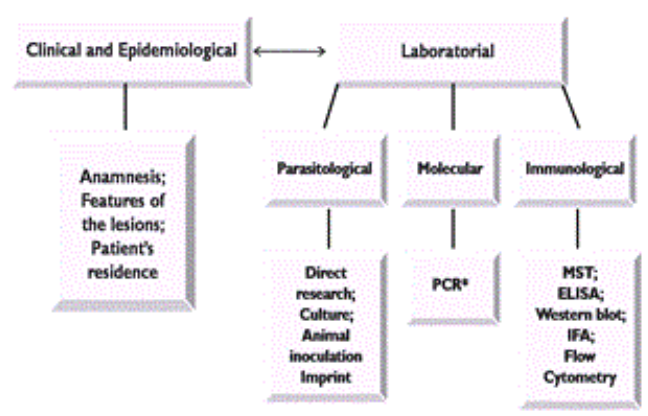

Figure 3: Simplified scheme of ATL diagnosis. ${ }^{*}$ Molecular diagnosis is not normally considered in routine, despite it's increasingly use in research centers.

A conclusive diagnosis is achieved when the direct research of the parasite amastigote through microscopy; the isolation of the parasites in culture medium or animal inoculation are positive $[7,16]$.

The direct research of the parasite can be performed using the scarified lesion, aspiration or biopsy of the lesion's edge. It is possible to visualize Leishmania spp. amastigotes by the method of Giemsa or Leishman [17]. This method has a sensitivity which varies from 50 to $70 \%$ [9]. The positivity of the test is inversely proportional to the time of the disease evolution. Although it is a simple technique, it has low cost, but cannot identify the parasite in all patients $[18,19]$.

Parasite isolation is performed in appropriate media, like NealNovy-Nicole, using obtained material from aspirative punction or biopsies of patients lesions. The sensitivity of the culture method is usually low, around 20 to $40 \%$. This is related mostly because of the absence of parasites in the lesions, mainly when it is Leishmania (Viannia) braziliensis $[18,20,21]$. For the in vitro culture, there is an inoculation in susceptible animals, such as the golden hamster (Mesocricetus auratus). Due to the long-time of follow-up until the formation of the ulcer in the animal and the costs for their maintenance, this method is restricted to research institutes $[7,18,22]$.

Regarding the molecular methods, the polymerase chain reaction (PCR) allows the amplification of specific genes of DNA from initiator oligonucleotides (primers) paired specifically with the target region, therefore allowing its use as a specific instrument for the diagnosis of several infectious diseases [22-25]. Although molecular approaches have been developed for ATL diagnosis and PCR is a high sensitive and specific technique, it is a sophisticated test for laboratorial use in routine protocols, with technical requirements and still a high cost $[21,26]$. 
The immunological diagnosis is based on the evaluation of the cellular response using the Montenegro Skin Test (MST) and/or the evaluation of the humoral response using the Indirect Immunofluorescence (IFA), enzyme-linked immunosorbent assay (ELISA) and Western blot. Currently there can be found in the literature works where flow cytometry appears as an alternative diagnostic tool for the disease, with advantages over the conventionally used methods [27-30].

The detection of the cellular response through the MST has been employed as an important resource on the immunological diagnosis of ATL due to its high sensitivity and specificity. This test consists on the injection of an antigenic suspension of killed promastigotes to induce a late hypersensitivity response, which is evaluated after 48 to 72 hours $[9,31]$. Although it can be positive in the majority of ATL cases (90\%), the result is negative in recent lesions, in the diffuse form and in immunosuppressed patients. In endemic areas it is commonly positive due to the presence of subclinical infections $[19,32]$. Besides that, this test does not differentiate active disease from past disease $[9,21,33]$.

Routine protocols based on IFA, ELISA and Western blot are performed for the diagnosis of ATL [34-36]. These tests present limitations, considering their lack of specificity and low reproducibility. Besides that, they might present crossed-reactions with another diseases caused by phylogenetically related species. It is also known that low levels of antibodies are observed in these tests, and there is an absence of correlation between the circulating antibody levels with the presence of an active infection [37-40].

\section{Diagnosis by flow cytometry}

In view of the inherent difficulties of the serological techniques used on the laboratorial routine for ATL diagnosis, new methodological approaches are being developed. Flow cytometry is a technology which allows a fast, objective and quantitative analysis of cells in suspension $[41,42]$. The cells from the samples are stained with fluorochromes, allowing their identification and quantification regarding their size, granularity and fluorescence intensity. This technique has several advantages when compared to the conventional immunoassays, such as the quantification of the analyte, use of a reduced sample volume, high reproducibility and sensitivity, and also, the possibility of multiplexing $[43,44]$.

This technology applied to ATL diagnosis by detecting anti-IgG antibodies against Leishmania braziliensis was firstly described by Rocha et al. [27], where they found levels of $93.6 \%$ of sensitivity in patients who had the active form of the disease $[27,45]$. This technique is based on the sensitization of 96-well plates with the patient's serum serially diluted and then on incubating it with the antigen, which can be the whole live/killed parasite or recombinant proteins bonded to micro-beads [45], furthermore, the plates are finally incubated with a secondary antibody which is bonded to a fluorochrome, allowing the visualization on the equipment $[28-30,45,46]$.

A study made by Oliveira et al. [28] showed that flow cytometry, when compared to IFA, showed a greater performance in detecting active disease and monitoring the cure of patients after treatment. This study pointed the possibility of using this technology not only to detect ATL in patients, but also to use it as a cure criterion. Having a laboratorial cure criterion would avoid discomfort to the patients, since the treatment is invasive and toxic.

More recently, a work performed by Teixeira-Carvalho [47] was able to make a differential diagnosis between Chagas disease, ATL and
Visceral Leishmaniasis. It was a triplex flow cytometry assay based on the detection of IgG1 antibodies against each disease. Although the protocols which were used demand high technology equipments and expensive reagents, it points to the right path researchers should follow to achieve better results in diagnosing this disease using this technology.

The use of flow cytometry is becoming more frequent nowadays, being easier to access this technology in almost every research institute. Although there is a limitation due to the associated cost, the benefits that comes with the positive results for society outweighs these barriers.

\section{Conclusions}

ATL is considered a neglected disease. It affects mainly developing countries, causing great morbidity in patients due to the difficult access to treatment and lack of a good healthcare system. Owing to the low income of resources to these areas, there is limited research dedicated for new diagnostic tools and also management and control of the disease.

There is an urgent need for new treatment options which are less toxic, mainly for children and those immunosuppressed patients. The available treatment is being used for more than 50 years and the mechanism of action of these drugs are still not completely known.

Vaccination remains being the best alternative to control the Leishmaniasis. The development of an efficient, safe and profitable vaccine is a global and critical priority for public health, but it is still not a reality.

Since there is no effective treatment with low toxicity and no vaccines available for ATL yet, the best way to try to control the disease is to have good diagnostic tools. These diagnostic tools would ideally detect the disease in the early stages and determine a cure criterion, within the treatment, that would allow the patients to know whether their disease is cured or not. Therefore, enhancing specificity using modern technologies like flow cytometry, using molecularly defined antigens and performing multiplex assays aiming differential diagnosis is probably the best path to achieve a superior diagnostic method for a better control of the disease.

\section{Aknowledgements}

We are thankful for our colleagues of the Immunogenetics Laboratory; Aggeu Magalhães Research Center and the Federal University of Pernambuco. We also thank the funding agencies FACEPE, CAPES and CNPq.

\section{References}

1. Elmahallawy EK, Martinez AS, Granger JR, Mallecot YH, Agil A, et al. (2014) Diagnosis of leishmaniasis. J Infect Dev Ctries8: 961-72.

2. Pourmohammadi B, Motazedian M, Hatam G, Kalantari M, Habibi P, et al. (2010) Comparison of Three Methods for Diagnosis of Cutaneous Leishmaniasis. Iranian J Parasitol 5: 1-8.

3. Leishmaniasis, World Health Organization. Accessed on 19 Mar 2016.

4. Marzochi MCA (1992) Leishmanioses no Brasil. As leishmanioses tegumentares. J Basic Microbiol 63: 82-104.

5. Grimaldi G Jr, Tesh RB (1993) Leishmaniases of the New World: current concepts and implications for future research. Clin Microbiol Rev 6: 230-50. 
6. Bacellar O, Lessa H, Schriefer A, Machado P, Jesus ARD, et al. (2002) Upregulation of Th1-type responses in mucosal leishmaniasis patients. Infect Immun70: 6734-6740

7. Brasil (2007) Manual de Vigilância da leishmaniose tegumentar americana. Ministério da Saúde, [2edn]; Brasília, DF.

8. Gontijo B, Carvalho MLR (2003) Leishmaniose Tegumentar Americana. Ver Soc Bras Med Trop 36: 71-80.

9. Goto H, Lindoso JAL (2010) Current diagnosis and treatment of cutaneous and mucocutaneous leishmaniasis. Expert Rev Anti Infect Ther 8: 419-433.

10. Kedzierski L (2010) Leishmaniasis Vaccine: Where are We Today? J Glob Infect Dis 2: 177-185.

11. Mutiso JM, Macharia JC, Kiio MN, Ichagichu JM, Rikoi H, et al. (2013) Development of Leishmania vaccines: predicting the future from past and present experience. J Biomed Res 27: 85-102.

12. Field V, Gautret P, Schlagenhauf P, BurchardGD, Caumes E. et al. (2010) Travel and migration associated infectious diseases morbidity in Europe. BMC Infect Dis 10: 330

13. Gomes MC, de Paula NA, Morais OO, Soares KA, Roselino AM, et al. (2014) Complementary exams in the diagnosis of american tegumentary leishmaniasis. An Bras Dermatol 89: 701-709.

14. Neves DP (2005) Parasitologia humana [10edn]; Atheneu, São Paulo.

15. Andrade MS, Brito ME, Silva ST, Lima BS, Almeida EL, et al. (2005) Leishmaniose tegumentar americana causada por Leishmania (Viannia) braziliensis, em área de treinamento militar na Zona da Mata de Pernambuco. RevSocBrasMedTrop 38: 229-33.

16. Machado PE (2004) Comparação dos métodos parasitológico, imunológico e molecular na detecção de Leishmania spp. em amostras de pacientes com leishmaniose tegumentar americana no Estado de Santa Catarina.Universidade Federal de Santa Catarina, Florianópolis, Brasil.

17. Neves DP, Melo LA, Genaro O, Linardi PM (2000) Parasitologia Humana (10thedn). Atheneu, São Paulo.

18. Bensoussan E, NasereddinA, Jonas F, Schnur LF, Jaffe CL (2006) Comparison of PCR assays for diagnosis of cutaneous leishmaniasis. J ClinMicrobiol 44: 1435-1439.

19. Vega-López F (2003) Diagnosis of cutaneous leishmaniasis. Curr Opin Infect Dis 16: 97-101.

20. Brandão-Filho SP, Campbell-Lendrum D, Brito ME, Shaw JJ, Davies CR (1999) Epidemiological surveys confirm an increasing burden of cutaneous leishmaniasis in north-east Brazil. Trans R Soc Trop Med Hyg 93: 488-494.

21. Reithinger R, Dujardin JC, Louzir H, Pirmez C, Alexander B, et al. (2007) Cutaneous leishmaniasis. Lancet Infect Dis 7:581-596.

22. Rodrigues EHG (2000) Validação de abordagens moleculares para o diagnóstico da leishmaniose tegumentar americana em Pernambuco. Oswaldo Cruz Foundation, Pernambuco, Brazil.

23. Gomes ML, Galvao LM, Macedo AM, Pena SD, Chiari E (1999) Chagas disease diagnosis: comparative analysis of parasitologic, molecular, and serologic methods. Am J Trop Med Hyg. 60: 205-210.

24. Rodrigues EH, Felinto de Brito ME, Mendonça MG, Werkhäuser RP, Coutinho EM, et al. (2002) Evaluation of PCR for diagnosis of American Cutaneous Leishmaniasis in an Area of endemicity in Northeastern Brazil. J Clin Microbiol 40: 3572-3576.

25. Singh B (1997) Molecular methods for diagnosis and epidemiological studies of parasitic infections. Int J Parasitol 27: 1135-1145.

26. De Assis Souza M, De Castro MC, De Oliveira AP, De Almeida AF, De Almeida TM, et al. (2013) Cytokines and NO in American tegumentary leishmaniasis patients: Profiles in active disease, after therapy and in selfhealed individuals. Microb Pathog 57: 27-32.

27. Rocha RD, Gontijo CM, Elói-Santos SM, Teixeira Carvalho A, CorrêaOliveira R, et al. (2002) Anticorposantipromastigotas vivas de Leishmania (Viannia) braziliensis, detectados por citometria de fluxo, para identificação da infecção ativa na leishmaniose tegumentar americana. Ver Soc Bras Med Trop 35: 551-62.
28. De Oliveira AP, De Castro MC, De Almeida AF, Souza Mde A, De Oliveira BC, et al. (2013) Comparison of flow cytometry and indirect immunofluorescence assay in the diagnosis and cure criterion after therapy of American tegumentaryleishmaniasis by anti-live Leishmania (Viannia) braziliensis immunoglobulin G. J Immunol Methods 387: 245-253.

29. Pissinate JF, Gomes IT, Peruhype-Magalhães V, Dietze R, Martins-Filho $\mathrm{OA}$, et al. (2008) Upgrading the flow-cytometric analysis of antiLeishmania immunoglobulins for the diagnosis of American tegumentary leishmaniasis. J Immunol Methods 336: 193-202.

30. Pereira VR, Reis Lde C, Souza Mde A, De Oliveira AP, De Brito ME, et al. (2012) Evaluation of anti-lived and anti-fixed Leishmania (Viannia) braziliensis promastigote IgG antibodies detected by flow cytometry for diagnosis and post-therapeutic cure assessment in localized cutaneous leishmaniasis. Diagn Microbiol Infect Dis 74: 292-298.

31. Machado PE (2004) Comparação dos métodos parasitológico, imunológico e molecular na detecção de Leishmania spp. em amostras de pacientes com leishmaniose tegumentar americana no Estado de Santa Catarina. Master Dissertation. Federal University of Santa Catarina, Florianópolis, Brazil.

32. Reis LC (2007) Caracterização da resposta imune celular em portadores de leishmaniose tegumentar americana antes e após tratamento quimioterápico. Fundação Oswaldo Cruz, Pernambuco, Brasil.

33. Weigle KA, Labrada LA, Lozano C, Santrich C, Barker DC (2002) PCRbased diagnosis of acute and chronic cutaneous leishmaniasis caused by Leishmania (Viannia). J Clin Microbiol 40: 601-606.

34. Brito ME, Mendonça MG, Gomes YM, Jardim ML, Abath FG (2000) Identification of potentially diagnostic Leishmania braziliensis santigens in human cutaneous leishmaniasis by immunoblot analysis. Clin Diagn Lab Immunol 7: 318-321.

35. Brito ME, Mendonça MG, Gomes YM, Jardim ML, Abath FG (2001) Dynamics of the antibody response in patients with therapeutic or spontaneous cure of American cutaneous leishmaniasis. Trans R Soc Trop Med Hyg. 95: 203-206.

36. Kar K (1995) Serodiagnosisofleishmaniasis. CritRevMicrobiol 21: 123-152.

37. Alves WA, Bevilacqua PD (2004) Reflexões sobre a qualidade do diagnóstico da leishmaniose visceral canina em inquéritos epidemiológicos: o caso da epidemia de Belo Horizonte, Minas Gerais, Brasil, 1993-1997. Cad Saude Publica 20: 259-65.

38. Schallig HD, Oskam L (2002) Molecular biological applications in the diagnosis and control of leishmaniasis and parasite identification. Trop Med Int Health 7: 641-651.

39. Passos VM, Barreto SM, Romanha AJ, Krettli AU, Volpini AC, et al. (2000) American cutaneous leishmaniasis: use of a skin test as a predictor of relapse after treatment. Bull World Health Organ 78: 968-974.

40. Savani ES, Schimonsky BvBv, Camargo MC, D'auria SR (2003) Vigilância de leishmaniose visceral americana em cães de área não endêmica, São Paulo. Ver Saude Publica 37: 260-262.

41. Faldyna M, Levá L, Knötigová P, Toman M (2001) Lymphocyte subsets in peripheral blood of dogs - a flow cytometric study. Vet Immunol Immunopathol 82: 23-37.

42. Nakage APM, Santana AE, Capua MLB, Coelho PS (2005) Flow cytometry methodology and application in the veterinary hematology. CiencRural 35: 966-973.

43. Sousa S, Cardoso L, Reed SG, Reis AB, Martins-Filho OA, et al. (2013) Development of a fluorescent based immunosensor for the serodiagnosis of canine leishmaniasis combining immunomagnetic separation and flow cytometry. PLoS Negl Trop Dis 7: e2371.

44. Jani IV, Janossy G, Brown DW, Mandy F (2002) Multiplexed immunoassays by flow cytometry for diagnosis and surveillance of infectious diseases in resource-poor settings. Lancet Infect Dis 2: 243-250.

45. De Paiva-Cavalcanti M, De Morais RC, Pessoa-E-Silva R, Trajano-Silva LA, Gonçalves-de-Albuquerque Sda C, et al. (2015) Leishmaniases diagnosis: an update on the use of immunological and molecular tools. Cell Biosci 5:31. 
Citation: Oliveira BC, Mendes APO, Castro MCAB, Hernandes VP (2016) American Tegumentary Leishmaniasis and Flow Cytometry: A Review. J Med Microb Diagn 5: 222. doi:10.4172/2161-0703.1000222

Page 5 of 5

46. Sousa S, Cardoso L, Reed SG, Reis AB, Martins-Filho OA, et al. (2013) Development of a fluorescent based immunosensor for the serodiagnosis of canine leishmaniasis combining immunomagnetic separation and flow cytometry. PLoS Negl Trop Dis 7: e2371.
47. Teixeira-Carvalho A, Campos FM, Geiger SM, Rocha RD, De Araújo FF, et al. (2015) FC-TRIPLEX Chagas/Leish IgG1: a multiplexed flowcytometry method for differential serological diagnosis of chagas disease and leishmaniasis. PLoSOne 10: e0122938. 